\title{
Age Friendly Cities on Active and Healthy Aging; One on Bolu-Karacasu Studio Experience
}

\author{
K. Pinar Kirkik Aydemir \\ Bolu Abant Izzet Baysal University, Department of Urban and Regional Planning \\ 14300 Bolu, Golkoy-Turkey \\ E-mail: kiymetpinar.aydemir@ibu.edu.tr
}

\begin{abstract}
The proportion of the elderly population to the general population is increasing day by day in our country and in the world. This situation mainly affects developing countries, but there are impacts on the developed countries as well. The global aging of the world's population increases the need for services for the elderly, thus making it necessary to address the situation in terms of urban living conditions and architectural aspects. The loss of the elderly's ability to adapt to the built environment, physical and biological constraints, and spatial inadequacies are forcing older people to change the boundaries of their habitat. Within this context, the World Health Organization (WHO) is leading the way in inspiring cities to be "age-friendly" through the Global Age-Friendly Cities Guide. It develops strategies for active aging and age-friendly cities that make the best use of health, participation, and safety opportunities to improve life quality in old age.

The main purpose of this study is to propose an application based on the theoretical infrastructure about the concept and requirements of the age-friendly city, which aims to create a livable and accessible environment in which the elderly can continue their lives actively and feel integrated with the society. In the scope of the study, an age-friendly city model for active and healthy aging was developed, and its results were analyzed through the Age-friendly Bolu Karacasu sample, which was created with a project in the Urban Planning Project Studio of Abant Izzet Baysal University of Bolu in 2019-2020.
\end{abstract}

Keywords: Age Friendly Cities, active aging, quality of life, accessibility, Bolu-Karacasu.

DOI: $10.7176 / \mathrm{JSTR} / 6-10-05$

\section{Aktif ve Sağlıklı Yaşlanma Üzerine Yaş Dostu Şehirler; Bolu- Karacasu Üzerinde Bir Stüdyo Deneyimi}

\begin{abstract}
Özet
Ülkemizde ve dünyada yaşlı nüfusunun genel popülasyon oranı gün geçtikçe artmaktadır. Bu durum, başta gelişmiş ülkeler olmak üzere gelişmekte olan ülkeleri de derinden etkilemektedir. Dünya nüfusunun küresel olarak yaşlanması, yaşlılara yönelik hizmetlere olan ihtiyacı arttırmakta, dolayısıyla durumun kentsel yaşam koşulları ve mimari boyutuyla ele alınmasını gerekli kılmaktadır. Yaşlılarda yapılı çevreye uyum yeteneğinin azalması, fiziksel, biyolojik kısıtlılıklar ve yaşanılan mekansal yetersizlikler, yaşı insanlarda yaşam alanının sınırlarını değiştirmeye zorlamaktadır. Bu kapsamda Dünya Sağlık Örgütü (WHO) Küresel Yaş Dostu Şehirler Rehberi aracılığı ile şehirlerin "yaş dostu" olmaları için ilham vermeye öncülük etmektedir. Yaşlılıkta yaşam kalitesinin değerini artırmak için sağlık, katılım ve güvenlik olanaklarını en iyi şekilde değerlendiren, aktif yaşlanma ve yaş dostu şehirler için stratejiler geliştirmektedir.

$\mathrm{Bu}$ çalışmanın temel amacı yaşlıların topluma entegre bir şekilde, yaşamlarını aktif devam ettirebilecekleri, yaşanılabilir ve erişilebilir bir ortam oluşturmayı amaçlayan Yaşlı dostu kent kavramı ve gereksinimleri noktasındaki teorik alt yapı bağlamında bir uygulama önerisinde bulunmaktır.
\end{abstract}

55 | P a g e

www.iiste.org 
Çalı̧sma kapsamında 2019-2020 Bolu Abant İzzet Baysal Üniversitesi Mimarlık Fakültesi Şehircilik Projesi stüdyosunda proje konusu olarak Yaşlı Dostu Bolu Karacasu örneği üzerinden aktif ve sağlıklı yaşlanma için bir yaş dostu şehir modeli örneği geliştirilmiş ve sonuçları analiz edilmiş̧ir.

Anahtar Kelimeler: Yaş dostu şehirler, aktif yaşlanma, yaşam kalitesi, erişilebilirlik, Bolu-Karacasu.

\section{Giriş}

\subsection{Yaşlılık ve Yaşlanmada Yaşam Kalitesi Arayıșı}

Yaşl1l1k bireylerin tüm yaşam döngülerinin üȩüncü ya da dördüncü evresine denk gelen, bireyin biyolojik açıdan eski yetisini kaybetmesi, kendine bakamayacak duruma gelmesi ya da bir başkasının yardımına ihtiyaç duyması şeklinde yaşamını sürdürdüğü dönem olarak ifade edilebilir (Jönsson,2018). Dünya Sağlık Örgütü (WHO) yaşlılık sınırını 65 yaş olarak kabul etmektedir. Bu çerçevede 45-59 yaş aralığı ortayaş, $60-74$ yaş aralığ yaşlılık, $75-89$ yaş aralığ ileri yaşl1lık, 90 ve üstü ise ihtiyarlık olarak kabul edilmektedir (Koçak, 2010).

Öte yandan 2015 ve 2030 yılları arasında dünyada 60 yaş ve üzerindeki nüfusun $\% 56$ oranında büyüyerek 901 milyondan 1.4 milyara ulaşacağı, 2050 yılında bu nüfusun 2.1 milyar, 2100'de ise 3.2 milyar (\% 28.6) olacağı beklenmektedir. "80 yaş ve üzeri" nüfusun ise dünya genelindeki yaşlı nüfustan daha hizlı büyümekte olduğu, 2015'de 125 milyon olan 80+ yaş nüfusunun, 2050'de 434 milyona, 2100'de 944 milyona ulaşacağı tahmin edilmektedir (United Nations, 2015).Türkiye'de ise 65 ve yukarı yaştaki nüfus 2012'de 5 milyon 682 bin 300 kişi iken, 2016'da 6 milyon 651 bin 503 kişiye ulaşmıştır. Yaşlı yaş grubunun gelecek 30 yıl içerisinde toplam nüfusun yüzde 20,8'ini kapsayacağ 1 yönünde istatistiksel sonuçlar vardır (Ünlü, 2018).

Yaşlanma süreci fiziksel, algısal ve bilişsel olarak; fonksiyon azalması, kas gücü kaybı, bireyin daha hızlı yorulması, hareketlerin yavaşlaması, günlük yaşamın gerektirdiği pek çok fonksiyonun gerçekleştirilmesinde kısitlılıklar meydana getirmektedir (Kalınkara, 2015). Bu dönemde yaşlı insanlarda ortaya çıkan yeti kaybı, yaşılıarın günlük aktivitelerini, hareket alanlarını ve sosyal ilișkilerini olumsuz etkilemektedir. Dolayısıyla gerek dünya gerekse ülkemiz yaşlı nüfusundaki artı̣s "yaşlılarda yaşam kalitesi", aktif yaşlanma ve kentsel gereklilikler konuları üzerine çalışmaların yürütülmesini hızlandırmaktadır. Yaşlı grubun sosyal ve toplumsal bağlarını sürdürebilme ve yeni ilişkiler kurabilmesine olanak tanıyan, herkesle eşit, erişilebilir güvenli yaşam çevrelerine ihtiyaçları vardır.

Yaşam kalitesi ile iliş̧ili olan yaşlı dostu kenti kavramı da yukarıda bahsedilen adaptasyonları içeren fiziksel-eylem yapılandırmasıdır. Yaşlı dostu kenti kavramı özünde; var olma-(being);"kişinin, birey olarak kim olduğuna yanıt araması", ait olma-(belonging); "bireyin toplumla ve çevreyle etkileşimi", gerçekleștirme-(becoming); "bireyin yașamda kendisini tanımlaması" șeklinde ifade edilen eylemlere olan ihtiyacı karşılamaya yönelik girişimlerdir (Aslan, 2009). Yaşlanma ile birlikte insan yaşamında meydana gelen fiziksel, biyolojik ve psikolojik olumsuzluklar bireylerin yaşam kalitesinin ve konforunun azalmasına sebep olmaktadır. Yaşlı bireylerde yaşam kalitesi; fiziksel ve maddi iyi olma durumu, bos zaman aktiviteleri yapabilme, sosyal yașama katılım, duygusal ve psikolojik durum, aile ve arkadaş çevresi yanında politik, ekonomik faktörler vb. değişken faktörler ile doğrudan ilişsilidir (Arpac1, 2015).

Yaşlı insanlarda; duyu süreci ve algılamada, yön bulma, oryantasyon ve kavram becerisinde azalma, sıcaklık değişimlerine uyum becerisinde azalma, arka plan sesleri ile gürültüleri ayırmada zorluk vb. birtakım engeller ile karşılaşılabilmektedir. Tüm bu zorluklar, hareket etme yeteneklerinde kısıtlıklara neden olabileceği gibi görsel, sinirsel anlamda yetersizlikler şeklinde de görülebilir (Carstens, 1985). Günümüz ergonomi ve gelişmişlik düzeyi ile yaşlı bireyler için yapı iç tasarımları ile çeşitli çözümler sunulsa da, kamusal alanlarda müdahalenin sınırlı olduğu görülmektedir. Dolayısı ile yaşlıların hareketlerini kolaylaştıracak ve harekete teşvik edecek nitelikte kentsel mekan standartlarının geliştirilmesine ihtiyaç vardır.

İlk kez 2005 yılı XVIII. Dünya Gerontoloji ve Geriatri kongresinde aktif yaşlanma kavramı gündeme gelmiș olup, yaşlı insanların yaşam kalitesini yükseltmek amaçlı, yaşlı bireylerin kent içinde aktif olması ve aktif yaşlanmaya olanak sağlayacak çevresel standartlar belirtilmektedir (Tutal vd., 2009). Dünya Sağlık Örgütü tarafından yaşlı dostu kent çalışmasında 8 bileşen ile yaşlı dostu kent kavramı ele alınmaktadır. Bunlar; sırasıyla; dış mekanlar ve binalar, ulaşım, konut, sosyal katılım, toplumsal yaşama dahil olma ve toplumun yaşlıya saygısı, vatandaşlı görevini yerine getirme ve işgücüne katılım, bilgi edinme ve iletişim, toplum desteği ve sağlık hizmetleri şeklindedir (Akıncıtürk vd.,2019) Dolayısıyla yaşlı dostu kent, sadece yaşlı bireyler değil, çocuklar ve engelliler de dahil olmak üzere

56 | P a g e

www.iiste.org 
tüm toplum yararına olanak sağlayan düzenlemelerin yapıldığı ve gerekli tedbirlerin alındığı bir yaşam çevresi oluşturulması girişimidir. Her bireyin olduğu gibi, yaşlıların da rahat, uygun, güvenli ve sağlıklı bir ortamda yaşama hakları vardır. Yaşılıar için özellikle konut çevresi ile kentsel mekanın erişilebilirliği ve kullanılabilirliğine yönelik beklentiler bir bütün olarak yaşlılara yönelik yapılaşmış çevredeki politikaları tartışılır hale getirmektedir.

Hızla değişen çevresel koşullar ve kentleşme ile, küresel ve yerel ekonominin yapılı çevre üzerindeki yansımaları, toplumsal hareketler, sosyo-mekânsal ihtiyaçlar, yer ve bağlam gibi farklı paradigmaların; mimari ve planlamada stüdyo ortamında ele alınmasını desteklerken, talep ve koşullar karşısından farklı alternatifleri denemeye yönlendirmektedir (Turgut vd., 2019). Bu doğrultu üzerinden çalışma kapsamında 2019-2020 Bolu Abant İzzet Baysal Üniversitesi Mimarlık Fakültesi Şehircilik Projesi stüdyosunda Yaşlı Dostu Bolu Karacasu stüdyo deneyimi aktarılmıştır. Bu deneyimle ülkemiz ve Bolu ili özelinde yaşlı dostu şehirler için örnek bir model oluşturması hedeflenmiştir. Çalışmanın akış sürecinde;

-Aktif yaşlanma ve yaşlı dostu kent hedefleri üzerinde genel stratejiler belirtilmektedir.

-Kent parçası-kent bütünü etkileşimi Bolu Karacasu özelinde ve çevre yerleşmeler genelinde ele alınmaktadır.

- Çalışma alanı özelinde planlama ve tasarımı yönlendirebilecek doğal, kültürel peyzaj özellikleri tespit edilerek, alan analiz-sentez ilişkisine dayalı (swot analizi) olarak mevcut mekânsal kullanımlar çözümlenmektedir.

- Planlama/kentsel tasarım/kentsel mekan ilişki bütünlüğünü koruyarak yeniden yerleşim alanı için 1/5000 Nazım İmar Planı, 1/1000 Uygulama İmar planı önerilmektedir.

\subsection{Aktif Yaşlanma Ve Yaşı Dostu Kent Hedefleri}

Yaşlılık bireylerin tüm yaşam döngülerinin üçüncü ya da dördüncü evresine denk gelen, bireyin biyolojik açıdan eski yetisini kaybetmesi, kendine bakamayacak duruma gelmesi ya da bir başkasının yardımına ihtiyaç duyması şeklinde yaşamını sürdürdüğü dönem olarak ifade edilebilir (Jönsson,2018). Dünya Sağlık Örgütü (WHO) yaşlılık sınırını 65 yaş olarak kabul etmektedir. Bu çerçevede 45-59 yaş aralığı ortayaş, 60-74 yaş aralığı yaşlılık, 75-89 yaş aralığı ileri yaşlılık, 90 ve üstü ise ihtiyarlık olarak kabul edilmektedir (Koçak, 2010).

Öte yandan 2015 ve 2030 yılları arasında dünyada 60 yaş ve üzerindeki nüfusun $\% 56$ oranında büyüyerek 901 milyondan 1.4 milyara ulaşacağı, 2050 yılında bu nüfusun 2.1 milyar, 2100'de ise 3.2 milyar (\% 28.6) olacağ 1 beklenmektedir. "80 yaş ve üzeri” nüfusun ise dünya genelindeki yaşlı nüfustan daha hızlı büyümekte olduğu, 2015'de 125 milyon olan 80+ yaş nüfusunun, 2050'de 434 milyona, 2100'de 944 milyona ulaşacağı tahmin edilmektedir (United Nations, 2015).Türkiye'de ise 65 ve yukarı yaştaki nüfus 2012'de 5 milyon 682 bin 300 kişi iken, 2016'da 6 milyon 651 bin 503 kişiye ulaşmıştır. Yaşlı yaş grubunun gelecek 30 yıl içerisinde toplam nüfusun yüzde 20,8 ini kapsayacağ yönünde istatistiksel sonuçlar vardır(Ünlü, 2018).

Yaşlanma süreci fiziksel, algısal ve bilişsel olarak; fonksiyon azalması, kas gücü kaybı, bireyin daha hızlı yorulması, hareketlerin yavaşlaması, günlük yaşamın gerektirdiği pek çok fonksiyonun gerçekleştirilmesinde kısttlılıklar meydana getirmektedir (Kalınkara, 2015). Bu dönemde yaşlı insanlarda ortaya çıkan yeti kaybı, yaşlıların günlük aktivitelerini, hareket alanlarını ve sosyal ilişkilerini olumsuz etkilemektedir. Dolayısıyla gerek dünya gerekse ülkemiz yaşlı nüfusundaki artış "yaşlılarda yaşam kalitesi",aktif yaşlanma ve kentsel gereklilikler konuları üzerine çalışmaların yürütülmesini hızlandırmaktadır. Yaşlı grubun sosyal ve toplumsal bağlarını sürdürebilme ve yeni ilişkiler kurabilmesine olanak tanıyan, herkesle eşit, erişilebilir güvenli yaşam çevrelerine ihtiyaçları vardir.

Yaşam kalitesi ile ilişkili olan yaşıı dostu kenti kavramı da yukarıda bahsedilen adaptasyonları içeren fiziksel-eylem yapılandırmasıdır. Yaşlı dostu kenti kavramı özünde; var olma-(being);"kişinin, birey olarak kim olduğuna yanit araması", ait olma-(belonging); "bireyin toplumla ve çevreyle etkileşimi", gerçekleştirme-(becoming); "bireyin yaşamda kendisini tanımlaması" şeklinde ifade edilen eylemlere olan ihtiyacı karşılamaya yönelik girişimlerdir (Aslan, 2009). Yaşlanma ile birlikte insan yaşamında meydana gelen fiziksel, biyolojik ve psikolojik olumsuzluklar bireylerin yaşam kalitesinin ve konforunun azalmasına sebep olmaktadır. Yaşlı bireylerde yaşam kalitesi; fiziksel ve maddi iyi olma durumu, boş zaman aktiviteleri yapabilme, sosyal yaşama katılım, duygusal ve psikolojik durum, aile ve arkadaş çevresi yanında politik, ekonomik faktörler vb. değişken faktörler ile doğrudan ilişkilidir (Arpac1, 2015).

Yaşlı insanlarda; duyu süreci ve algılamada, yön bulma, oryantasyon ve kavram becerisinde azalma,

57 | P a g e

www.iiste.org 
sıcaklık değişimlerine uyum becerisinde azalma, arka plan sesleri ile gürültüleri ayırmada zorluk vb. birtakım engeller ile karşılaşılabilmektedir. Tüm bu zorluklar, hareket etme yeteneklerinde kısıtlıklara neden olabileceği gibi görsel, sinirsel anlamda yetersizlikler şeklinde de görülebilir (Carstens, 1985). Günümüz ergonomi ve gelişmişlik düzeyi ile yaşıı bireyler için yapı iç tasarımları ile çeşitli çözümler sunulsa da, kamusal alanlarda müdahalenin sınırlı olduğu görülmektedir. Dolayısı ile yaşlıların hareketlerini kolaylaştıracak ve harekete teşvik edecek nitelikte kentsel mekan standartlarının geliştirilmesine ihtiyaç vardır.

İlk kez 2005 yılı XVIII. Dünya Gerontoloji ve Geriatri kongresinde aktif yaşlanma kavramı gündeme gelmiş olup, yaşlı insanların yaşam kalitesini yükseltmek amaçlı, yaşlı bireylerin kent içinde aktif olması ve aktif yaşlanmaya olanak sağlayacak çevresel standartlar belirtilmektedir (Tutal vd., 2009). Dünya Sağlık Örgütü tarafından yaşlı dostu kent çalışmasında 8 bileşen ile yaşlı dostu kent kavramı ele alınmaktadır. Bunlar; sırasıyla; dış mekanlar ve binalar, ulaşım, konut, sosyal katılım, toplumsal yaşama dahil olma ve toplumun yaşlıya saygısı, vatandaşlık görevini yerine getirme ve işgücüne katılım, bilgi edinme ve iletişim, toplum desteği ve sağlık hizmetleri şeklindedir (Akıncıtürk vd.,2019) Dolayısıyla yaşlı dostu kent, sadece yaşı bireyler değil, çocuklar ve engelliler de dahil olmak üzere tüm toplum yararına olanak sağlayan düzenlemelerin yapıldığı ve gerekli tedbirlerin alındığ bir yaşam çevresi oluşturulması girişimidir. Her bireyin olduğu gibi, yaşlıların da rahat, uygun, güvenli ve sağlıklı bir ortamda yaşama hakları vardır. Yaşlılar için özellikle konut çevresi ile kentsel mekanın erişilebilirliği ve kullanılabilirliğine yönelik beklentiler bir bütün olarak yaşlılara yönelik yapılaşmış çevredeki politikaları tartışılır hale getirmektedir.

Hızla değişen çevresel koşullar ve kentleşme ile, küresel ve yerel ekonominin yapılı çevre üzerindeki yansımaları, toplumsal hareketler, sosyo-mekânsal ihtiyaçlar, yer ve bağlam gibi farklı paradigmaların; mimari ve planlamada stüdyo ortamında ele alınmasını desteklerken, talep ve koşullar karşısından farklı alternatifleri denemeye yönlendirmektedir (Turgut vd., 2019). Bu doğrultu üzerinden çalışma kapsamında 2019-2020 Bolu Abant İzzet Baysal Üniversitesi Mimarlık Fakültesi Şehircilik Projesi stüdyosunda Yaşlı Dostu Bolu Karacasu stüdyo deneyimi aktarılmıştır. Bu deneyimle ülkemiz ve Bolu ili özelinde yaşlı dostu şehirler için örnek bir model oluşturması hedeflenmiştir. Çalışmanın akış sürecinde;

-Aktif yaşlanma ve yaşlı dostu kent hedefleri üzerinde genel stratejiler belirtilmektedir.

-Kent parçası-kent bütünü etkileşimi Bolu Karacasu özelinde ve çevre yerleşmeler genelinde ele alınmaktadır.

- Çalışma alanı özelinde planlama ve tasarımı yönlendirebilecek doğal, kültürel peyzaj özellikleri tespit edilerek, alan analiz-sentez ilişkisine dayalı (swot analizi) olarak mevcut mekânsal kullanımlar çözümlenmektedir.

- Planlama/kentsel tasarım/kentsel mekan ilişki bütünlüğünü koruyarak yeniden yerleşim alanı için 1/5000 Nazım İmar Planı, 1/1000 Uygulama İmar planı önerilmektedir.

\subsection{Aktif Yaşlanma Ve Yaşı Dostu Kent Hedefleri}

Aktif yaşlanma kavramı temelde aktivite teorisi üzerine söylemlerden türemiş olup, ilk kez 1960’l1 yıllarda "başarılı yaşlanma" kavramının bir bileşeni şeklinde kullanılmaya başlanmıştır (Çifcili, 2016). Dünya Sağlık Örgütü tarafından 2002, Madrid, Birleşmiş Milletler Dünya Yaşlanma Toplantısı'nda (United Nations World Assembly on Ageing) "yaşlıların toplumun üretken ve aktif bireyleri olarak yaşayabilmeleri için eyleme geçilmesi” gerektiğinden bahsedilerek, aktif yaşlanmanın belirleyicileri tespit edilmiştir. Yaşlı insanların "günlük yaşamda nasıl daha çok keyif alabilirliği”" araştırılarak, bu doğrultuda aktif ve kaliteli yaşlanmayı sağlayacak olan yaşlı dostu kentlerin kurulması ve mekânsal analizlerin tespiti vb. kentsel mekanı yaşlıların deneyimlemesine olanak tanıyan, fiziksel çevresel belirleyiciler, sosyal aktiviteler ve hizmetler, nitelikli zaman geçirmeye yönelik aktivitelerin geliştirilmesi üzerinde durulmuştur (Murakami, ,2015).

2006 yılında da aktif ve sağlıklı yaşlanmayı teşvik etmek için 24 dünya ülkesi ve 33 şehirde "küresel yaşlı dostu şehir rehberi” hazırlanarak, tüm dünyada geçerli olabilecek temel kentsel standartlar belirlenmiştir (Yıldızak, 2017).

Yaşlı bireylerin kent yaşamına aktif katılımı, kentsel tasarım, erişilebilirlik, ulaşım, mahalle düzeni, konut, sosyal ve fiziki çevre koşulları gibi sosyo-mekansal gereksinmeler ile birlikte sosyal hizmet, iş alanları ve ekonomi vb. konuları da ilgilendirmektedir. Özellikle kentsel çevrenin erişilebilir nitelikte olması gündelik yaşama katılmayı sağlamada temel özelliktir (Tutal vd., 2009). Erişilebilirlik, yaşlı, engelli ve çocuklar dahil her gruptan insanın, kent yaşamına aktif katılımı açısından oldukça önemlidir. Yaşlıların mevcut toplumsal ve sosyal çevrelerinde olup bitenlere katılım sağlayabilmeleri ve yeni

58 | P a g e

www.iiste.org 
ilişkiler kurabilmeleri, erişilebilir güvenli bir kentsel çevre ile gerçekleşebilmektedir (Akıncıtürk vd., 2019)

Kentsel alanda yaşlıların karşılaştıkları zorlukların başında hareketlilik, faaliyet ve destek ihtiyacı, fiziksel güvenlik tehditleri ve sınırlı erişim gelmektedir. Yaş artışı ile organ ve işlevlerde bozulmalar, fiziksel, psikomotor, duyusal ve algısal yetkinliğin azalması vb. rahatsızlıklar gözlenmektedir (Kalınkara,2017).

Yaşılar ile ilgili hakların da geçtiği insan hakları bildirgesine bakıldığında ise ilk olarak Avrupa Sosyal Şartının 23. Maddesi; sosyal koruma hakkı ile yaşlıların;

- "kamusal, sosyal ve kültürel yaşama etkin olarak katılmalarına imkan veren iyi yaşam sürmelerine yönelik yeterli ihtiyacı karşılayabilen kaynak ve yeterliliklerin temini”"

- yaşlılar için var olan hizmetler ve kolaylıklar ile onların yararlanmalarına imkan veren bilgiyi içerme ve yaşlıların olabildiğince herkes gibi bütün haklara sahip olmaları,

- yaşlı insanların sağlığı için uygun konutlar ve konutların oluşturulması,

- sağlık bakım ve hizmetleri yoluyla yaşlıların kendi yaşam biçimlerini hiç kimseye bağlı olmadan idame ettirebilmeleri,

- kurumlarda yaşayan yaşlılara, özel yaşama saygı disiplini içerisinde, uygun yardım temini ve kendi yaşam koşullarına ilişkin kararlarda aktif katılımlarını sağlamayı amaçlayan bir dizi önlemler alınması" taahhüt edilmektedir.

Bildirgenin 25. maddesinde ise, yaşlılara yönelik düzenlemelerde; "Birlik, yaşlıların, onurlu ve bağımsız bir yaşam sürdürme ve sosyal ve kültürel yaşama katılma haklarını tanımakta ve saygl göstermektedir (Yanardağ, 2019.).

İnsan Hakları Bildirgesinde de belirtildiği gibi yaşlı insanların kendilerini rahat, bağımsız ve mutlu hissedebilecekleri yaşam çevrelerine ihtiyaçları vardır. Yaşı Dostu Kent ile de aktif yaşlanmayı destekleyen kapsamlı ve erişilebilir kentsel çevreler oluşturulması hedeflenmektedir. Dünyanın dört bir yanındaki şehirler ve topluluklar, daha yaş dostu olmak için çalışmalarını sürdürmektedir. DSÖ Küresel A ̆̆ 1 , yaşlanıldığında daha iyi yerler oluşturulması üzerine fiziksel ve sosyal ortamlarda birtakım hedefler ortaya koymaktadır (Tablo 1) (URL1).

Tablo 1. Yaşlı Dostu Kent İçin DSÖ tarafından desteklenen hedefler (T.C. Amasya Üniversitesi, 2011'den yararlanılarak yorumlanmıştır).

\begin{tabular}{|l|l|}
\hline Dış Mekanlar ve Binalar Açısından; & Ulaşım Açısından; \\
\hline $\begin{array}{l}\text { Kamusal alanlar temiz ve memnun edici } \\
\text { olmalıdır. }\end{array}$ & $\begin{array}{l}\text { Kamuda ulaşım ücretleri karşılanabilir, açıç̧a } \\
\text { belirtilmiş ve aynı ücrette olmalıdır. }\end{array}$ \\
\hline $\begin{array}{l}\text { Yeşil alanlar ve kamusal açık mekânlarda } \\
\text { oturma elemanları bakımlı, güvenilir ve } \\
\text { sayıca yeterli olmalıdır. }\end{array}$ & $\begin{array}{l}\text { Kamu ulaşımı geceleri, hafta sonu ve tatillerde } \\
\text { de çalışmalı ve güvenilir, sık saat aralıklarında } \\
\text { düzenlenmelidir. }\end{array}$ \\
\hline $\begin{array}{l}\text { Kaldırımlar yürümeye engel olmamalı, eğim } \\
\text { açısından \%4’ten fazla eğim içermemeli, yaya } \\
\text { erişilebilirliğine uygun olmalıdır. }\end{array}$ & $\begin{array}{l}\text { Kamu araçlarıbakımı yapılmış, erişilebilir, } \\
\text { aşı̈ı kalabalık olmayacak şekilde } \\
\text { düzenlenmeli ve araçlarda öncelikli kişiler } \\
\text { (yaşlı/engelli/hamile) için oturma yerleri } \\
\text { bulundurulmalıdır. }\end{array}$ \\
\hline $\begin{array}{l}\text { Bisiklet yolları ayrı bir yol olarak, paylaşımlı } \\
\text { cadde uygulaması kapsamında kaldırım ve } \\
\text { diğer yaya yollarından bağımsız tasarlanmış } \\
\text { olmalıdır. }\end{array}$ & $\begin{array}{l}\text { Engelli kişiler için ayrıca ulaştırma şekilleri } \\
\text { oluşturulmalıdır. }\end{array}$ \\
\hline $\begin{array}{l}\text { Yaşlı insanlara yönelik ayrı bir müşteri hizmet } \\
\text { ve memnuniyet birimi oluşturulmalıdır. }\end{array}$ & $\begin{array}{l}\text { Kullanıcılara hareket saatleri, güzergâhlar ve } \\
\text { özel ihtiyaçlarındaki olanaklar ile ilgili olarak } \\
\text { tam ve kolay erişilebilir şekilde bilgi } \\
\text { verilmelidir. }\end{array}$ \\
\hline $\begin{array}{l}\text { Hizmetler bir arada konumlanmış ve } \\
\text { erişilebilir düzeyde olmalıdır. }\end{array}$ & $\begin{array}{l}\text { Engelli ya da özel bir durumu olan kişiler için } \\
\text { otoparklar ve sürücü dinlenme alanları ayrı } \\
\text { planlanmalı ve bunlara saygı gösterilmelidir. }\end{array}$ \\
\hline
\end{tabular}

59 | P a g e 


\begin{tabular}{|c|c|}
\hline Konut Açısından; & Sosyal Katılım Açısından; \\
\hline $\begin{array}{l}\text { Konut alanları planlarken kamusal hizmetlere } \\
\text { ve toplumun geri kalan kısmına yakın, } \\
\text { güvenilir yerler tercih edilmeli, yeterli ve } \\
\text { ödenebilir şartlar oluşturulmalıdır. }\end{array}$ & $\begin{array}{l}\text { Çeşitli aktivite ve etkinlik için bir araya gelme } \\
\text { mekânları erişilebilir, iyi 1şıklandırılmış ve } \\
\text { kamu ulaşım ağının kolayca ulaşabildiği, } \\
\text { uygun konuma sahip yerlerde olmalıdır }\end{array}$ \\
\hline $\begin{array}{l}\text { Konut alanları, depreme dayanıklı ve } \\
\text { malzeme seçimi iyi inşa edilmiş, her türlü } \\
\text { hava şartlarına ve doğal tehditlere karşı } \\
\text { güvenli, konforlu, rahat olmalıdır. }\end{array}$ & $\begin{array}{l}\text { Aktiviteler ve çeşitli programlar ödenebilir } \\
\text { ücretlerde olup, ekstra maliyet içermemelidir. }\end{array}$ \\
\hline $\begin{array}{l}\text { Yaşlılar için evde bakım hizmetleri yeterli ve } \\
\text { ödenebilir, destekleyici hizmetler mevcut ve } \\
\text { elverişli olmalıdır. }\end{array}$ & $\begin{array}{l}\text { Yaşlı insanların bir araya gelecekleri, yaşlılara } \\
\text { yönelik etkinlikler düzenlenmelidir. }\end{array}$ \\
\hline $\begin{array}{l}\text { Bina cepheleri ve iç mekânlar hareket için } \\
\text { kısıtlayıcı olmamalı, koridor alanları hareket } \\
\text { kabiliyeti açısından uygun olmalıdır. }\end{array}$ & $\begin{array}{l}\text { Aktivitelere katılım yalnız veya refakatçi } \\
\text { eşliğinde olabilecek özellikte olmalıdır. }\end{array}$ \\
\hline $\begin{array}{l}\text { Kamu ve özel kiralık konut stoğu, iyi, } \\
\text { bakımlı, temiz ve güvenli olmalıdır. }\end{array}$ & $\begin{array}{l}\text { Aktiviteler, olaylar yaşlı insanlara bilgi } \\
\text { akışının düzenli olmasına dikkat edilmelidir. }\end{array}$ \\
\hline $\begin{array}{l}\text { Konut tadilat imkânları ve tedariği uygun ve } \\
\text { ödenebilir olmalı ve bunları sağlayanlar } \\
\text { yaşlıların ihtiyaçlarından haberdar olmalı ve } \\
\text { bunları anlamalıdırlar. }\end{array}$ & $\begin{array}{l}\text { Yaşlı insanlarda içinde olmak üzere toplumun } \\
\text { tüm kesimlerinin rekreasyon merkezleri, } \\
\text { okullar, kütüphaneler, toplum merkezleri gibi } \\
\text { yerel toplum mahallerinde bir araya } \\
\text { getirilmesi sağlanmalıdır. }\end{array}$ \\
\hline \multirow{2}{*}{$\begin{array}{l}\text { Kırılgan, zayıf, engelli yaşlı kişiler için } \\
\text { yeterli ve ödenebilir konut imkanı } \\
\text { oluşturulmalı, hizmetlerinin yerel imkânlarla } \\
\text { sağlanabilmesine olanak içermelidir. }\end{array}$} & $\begin{array}{l}\text { Farklı kesimlere de hitap eden yaşlı insanların } \\
\text { oluşturduğu aktiviteler çeşitlendirilmelidir. }\end{array}$ \\
\hline & $\begin{array}{l}\text { Toplum içerisinde sosyal açıdan izole edilme, } \\
\text { dışlanma tehdidi altında olan kişiler için } \\
\text { düzenli ve tutarlı bir sosyal yardım imkanı } \\
\text { sağlanmalıdır. }\end{array}$ \\
\hline $\begin{array}{l}\text { Toplumsal Yaşama Dahil Olma } \\
\text { Toplumun Yaşlıya Saygısı Açısından; }\end{array}$ & $\begin{array}{l}\text { Vatandaşık Görevini Yerine Getirme ve } \\
\text { İşüicüne Katılım Açısından; }\end{array}$ \\
\hline $\begin{array}{l}\text {-Kamu, gönüllü kuruluşlar ve ticari kuruluşlar } \\
\text { sürekli olarak yaşlı insanlara hizmet kalitesini } \\
\text { artırmak ve daha iyi hizmet götürebilmek için } \\
\text { düzenli biçimde çalışmalıdır. }\end{array}$ & $\begin{array}{l}\text { Gönüllü yaşlılar için kişisel maliyetleri } \\
\text { karşılamak amacıyla eğitim, tanımlama, } \\
\text { rehberlik ve tazminlerle beraber esnek iş } \\
\text { seçenekleri bulunmalıdır. }\end{array}$ \\
\hline $\begin{array}{l}\text { Hizmetler ve ürünler değişen ihtiyaçlara göre } \\
\text { farklılaşmalıdır ve bu tercihler, kamu ve ticari } \\
\text { hizmetler tarafından karşılanmalıdır. }\end{array}$ & $\begin{array}{l}\text { Yaşlı işgücünün nitelikleri desteklenerek } \\
\text { teşvik edilmelidir. }\end{array}$ \\
\hline $\begin{array}{l}\text { Yaşlı insanlar medyada sıkça yer almalı, } \\
\text { olumlu olarak betimlenmeli ve yaşlılar } \\
\text { hakkında basmakalıp klişelerden } \\
\text { vazgeçilmelidir. }\end{array}$ & $\begin{array}{l}\text { Yaşlı insanlar için esnek ve ortalama gelirli iş } \\
\text { olanaklarının desteklenmesi gerekmektedir. }\end{array}$ \\
\hline $\begin{array}{l}\text { Toplumsal aktiviteler, olaylar belirli yaşların } \\
\text { ihtiyaç ve tercihlerine cevap verecek şekilde } \\
\text { tüm nesillerin ilgisini çekmelidir. }\end{array}$ & $\begin{array}{l}\text { İşe almada, elde tutmada, teşvikte veya iş } \\
\text { eğitiminde yalnızca yaşa göre ayırımın } \\
\text { yasaklanması gerekmektedir. }\end{array}$ \\
\hline
\end{tabular}

$60 \mid \mathrm{P}$ a g e 


\begin{tabular}{|c|c|}
\hline $\begin{array}{l}\text { Toplumsal aktiviteler içinde yaşlıların aileler } \\
\text { içinde bunlara katılması sağlanmalıdır. }\end{array}$ & $\begin{array}{l}\text { Yaşlı insanlar için kendi başlarına } \\
\text { yapabilecekleri işler teşvik edilmeli ve } \\
\text { desteklenmelidir }\end{array}$ \\
\hline $\begin{array}{l}\text { Hali vakti yerinde olmayan yaşlı insanlar, } \\
\text { kamusal, gönüllü ve özel hizmetlere kolayca } \\
\text { erişebilmelidirler } \\
\text { Çeşitli eğitim kurumları yaşlanma ve yaşlı } \\
\text { insanlar la ilgili bilgilendirme hususunda } \\
\text { firsatlar sunmal,, bu okul aktivitelerinde } \\
\text { yaşlılar da yer almalıdır. }\end{array}$ & $\begin{array}{l}\text { Yaşlı işgücü için emeklilik sonrası eğitim } \\
\text { programları uygulanmalıdır. }\end{array}$ \\
\hline $\begin{array}{l}\text { Yaşlı insanlar şu anki konumlarının yanı sıra } \\
\text { geçmişleriyle de toplumda fark edilmelidirler. }\end{array}$ & $\begin{array}{l}\text { Kamu, özel girişim ve gönüllü sektörlerdeki } \\
\text { karar verme organları yaşlı insanların } \\
\text { katılımını desteklemeli ve } \\
\text { kolaylaştırmalıdırlar. }\end{array}$ \\
\hline Bilgi Edinme Açısından; & $\begin{array}{l}\text { Toplum Desteği ve Sağlık Hizmetleri } \\
\text { Açısından; }\end{array}$ \\
\hline $\begin{array}{l}\text { Tüm yaştaki toplum üyelerine temel ve etkili } \\
\text { bir iletişim sistemi ulaşmalıdır. }\end{array}$ & $\begin{array}{l}\text { Sağlık için yeterli derecede sağlık ve } \\
\text { toplumsal destek hizmetleri bulunmalıdır. }\end{array}$ \\
\hline $\begin{array}{l}\text { Yaşlı insanların ilgisini çekebilecek düzenli } \\
\text { bilgiler ve yayınlar sunulmalıdır. }\end{array}$ & $\begin{array}{l}\text { Evde bakım hizmetleri sağlık olduğu kadar } \\
\text { kişisel bakım ve ev işlerini de kapsamalıdır. }\end{array}$ \\
\hline $\begin{array}{l}\text { Televizyon ve görüntülü medyada kullanılan } \\
\text { yazılar dahil olmak üzere tüm basılı bilgi } \\
\text { büyük harflerle okunaklı, temel fikirler kalın } \\
\text { olarak yazılmalıdır. }\end{array}$ & $\begin{array}{l}\text { Sağlık ve sosyal hizmetler uygun bir şekilde } \\
\text { yerleştirilmeli ve tüm ulaşım biçimleri } \\
\text { tarafından erişilebilir olmalıdır. }\end{array}$ \\
\hline $\begin{array}{l}\text { Yazılı ve diğer basın, basit, kısa, amaca } \\
\text { doğrudan ulaşan cümleler kurmalıdırlar. }\end{array}$ & $\begin{array}{l}\text { Yaşlı insanlar için sağlık ve sosyal hizmetler } \\
\text { hakkında güvenilir ve erişilebilir bilgi } \\
\text { sağlanmalıdır. }\end{array}$ \\
\hline $\begin{array}{l}\text { Telefon cevaplama hizmetleri bilgileri } \\
\text { yavaşça vermeli, her defasında karşıdakinin } \\
\text { anlayıp anlamadığını kontrol eden } \\
\text { mekanizmalar oluşturulmalıdır. }\end{array}$ & $\begin{array}{l}\text { Tüm personel saygılı, yardımsever ve yaşlı } \\
\text { insanlara hizmet edecek şekilde eğitilmiş } \\
\text { olmalıdır. }\end{array}$ \\
\hline $\begin{array}{l}\text { Kamusal ve ticari hizmetler istem üzerine çok } \\
\text { yakın bire bir hizmetler sunabilmelidirler. }\end{array}$ & $\begin{array}{l}\text { Tüm yaşlardan gönüllü hizmetler teşvik } \\
\text { edilmeli ve desteklenmelidir. }\end{array}$ \\
\hline $\begin{array}{l}\text { Yaşlı insanlara bilişim hizmetleri konusunda } \\
\text { eğitimler verilmeli, sağl1k, kültürel faaliyetler } \\
\text { vb. konularda online platformlar ile } \\
\text { haberleşme olanakları geliştirilmelidir. }\end{array}$ & $\begin{array}{l}\text { Yaşlı insanların kırılganlığı ve kapasiteleri de } \\
\text { dikkate alınarak toplumsal acil durum } \\
\text { planlamaları tekrar ele alınmalıdır. }\end{array}$ \\
\hline
\end{tabular}

Tablo 1'de belirtildiği üzere, Yaşlı dostu kent, şehirlerin yaşlılar için olumlu özelliklerini geliştirirken, onları engelleyici unsurları azaltabilmek için evrensel standartlar geliştirmektir. Özellikle toplumda kuşaklararası ilişkilerin sürdürülebilirliğinin sağlanmasında yaşlıların sosyal yaşama katılımı sağlanmalıdır. Geleneklerin ve göreneklerin kuşaktan kuşağa aktarılması, yaşlıların tecrübelerinden faydalanılması, bu amaçla yaşlıların topluma katılımı, yaşlı insanların yaşam memnuniyetini sağlamanın yanı sıra, yaşamdan keyif almaları ve mutlu olmalarına da olanak sağlamaktadır. Birçok dünya ülkesi yaşlıların sosyal yaşama katılmalarını destekleyici etkinlikler gerçekleştirmektedir. Bu kapsamda yaş dostu şehirler; sakinlerin, aileleri ile, yaşadıkları mahallelerinde ve sosyal çevrelerinde aktif olarak yaşlanmalarını sağlayan evrensel tasarım, engelli tasarım, herkes için eşitlikçi tasarım vb. kavramlardan yola çıkarak destekleyici bir yaşam ortamı hazırlamaya yönelik çalışmaları kapsamaktadır (Hoof vd.,2019).

$61 \mid \mathrm{P}$ a g e 
Yaşlı dostu kentlerin tasarımında yaşlı bireylerin sosyal kimlikleri incelenmesi şehir düzeni ve tasarımı açsısından önemlidir. Yaşlı kentleri için yaşlılarda mekan- davranış, mekan-dizim ilişkisini gözlemlemek gerekir. Mekan-davranış ilişkisinde, yaşlanma, yaşlılık (Gerontoloji) biliminin iyi anlaşılması, sosyal çevre, ekolojik uyum ve çevresel stres, yön bulma ve oryantasyon, çevre algısı (bilişssel haritalama), tercih, aidiyet, mahremiyet, kişisel alan vb. kavramların geniş bir perspektifle ele alınır (Peponis vd., 1990). Weissman (1981) yaşlı dostu kentini sadelik, akılda kalıcılık, tanımlanabilirlik ve yönlendirme olmak üzere belli başlıklarda tanımlamaktadır. Bu kapsamda girişçıkış yerleri, yoğunluklu kullanılan yerlerin sirkülasyon sistemi, mimari ögelerin görsel algısı, erişebilirliği ve yön bulma üzerinde durulmaktadır. Fiziksel çevrenin kolaylıkla algılanamaması ve kontrol edilememesi yaşlı bireylerde güven eksikliği ve kaygı duygusu oluşturmaktadır. Peyzaj ögesi olan su, duvarlar, heykeller, bitkiler yönlendirmede yardımcı olmakla birlikte yapı girişlerine bağlanan yolun vurgusunu artırmak açısından önemlidir (Arthur vd., 1992).

Yaşlı bireyler için kent tasarımı yapılırken kullanım açısından yoğun hizmet merkezlerinin (huzurevleri ve yaşlı bakımevlerinin) dış mekân tasarımında, öncelikle çeşitlilik ve kullanım kolaylığına dikkat edilmesi gerekmektedir. Dış mekândaki alanların tasarımında; doğanın hissedildiği, sağlık ve egzersiz için uygun, sosyal iletişime olanak tanıyan, içeriden dışarıya seyir imkanı oluşturan özellikler dikkate alınmalıdır (Kuş, 2019). Yine belirtilmesi gereken diğer bir konu da Yaşlı dostu kentler için yapılı çevrenin yaşlılıkta başkalarıyla tanışmaya ve sosyal katılıma olan katkısıdır. Konu uluslararası ölçekteki uygulamalar noktasında değerlendirmeye alınacak olursa yaşlı dostu kent kavramı, dünyanın her yerinde yaygın olmakla birlikte gelişmiş ülkelerin dünya nüfusunun yaşlanması ile de konuya eğilimlerin arttığı görülmektedir (VanHoof vd., 2018).Dünya yaşlı nüfus oranı en fazla olan ilk üç ülke, Fransa Monaco \%29,5; \%25,8 ile Japonya;\%21,1 ile Almanya olarak belirlenmiştir(Kozak vd..,2019). Nüfusu en yoğun ülkelerin yaşlı dostu şehirler için kentsel eğilimleri (Tablo 2)'de belirtildiği üzeredir.

Tablo 2. Dünya yaşlı nüfusu yüksek ülkelerde yaşlanma ve yaşam kalitesi üzerine çalışmalar (Koçak, 2010; Caner vd., 2013, Murokami,2015; Özdemir, 2017;Elmac1 vd.,2015).

\begin{tabular}{|c|c|c|}
\hline Fransa & Japonya & Almanya \\
\hline $\begin{array}{l}\text { Fransa'da yaşam koşullarını } \\
\text { iyileştirmeye yönelik çalışmalar, } \\
\text { halk sağlığı müdahaleleri ve } \\
\text { sağlık sektörünü geliştirmeye } \\
\text { dayanmaktadır. Aktif yaşlanma } \\
\text { ile ilgili olarak; yaşam boyu } \\
\text { öğrenmeyi sağlama, emekliliğe } \\
\text { geçişi kolaylaştırma, yaşlıları } \\
\text { aktif iş yaşamına kazandırmaya } \\
\text { yönelik politikalar } \\
\text { geliştirilmektedir }\end{array}$ & $\begin{array}{l}\text { Engelsiz toplum, sosyal } \\
\text { izolasyonu önlemek, kent içi } \\
\text { erişilebilirlik ve "yaşlıllğ̆ } \\
\text { olumlama" yönelimli } \\
\text { çalı̧malar devam etmektedir. } \\
\text { Özellikle yaşlıların akranları } \\
\text { ve diğer yaş grupları ile } \\
\text { etkileşime girmesini } \\
\text { kolaylaştırmak amaçlı, } \\
\text { "tazelenme } \\
\text { üniversitesi"projesi } \\
\text { geliştirilmektedir. }\end{array}$ & $\begin{array}{l}\text { Almanya'da farklı kuşakların } \\
\text { birbirleriyle etkileşim kurduğu } \\
\text { ve birbirlerini destekledikleri } \\
\text { toplum merkezleri projesi } \\
\text { devam etmektedir. Yaşlılar ve } \\
\text { gençler için gelecek odaklı ve } \\
\text { yenilikçi açı ve yeşil alanlar } \\
\text { tasarlanmaktadır. Yaşlı } \\
\text { insanların iş hayatına yeniden } \\
\text { kazandırılması amacıyla eğitim } \\
\text { programları yapılmaktadır. }\end{array}$ \\
\hline
\end{tabular}

Dünya ülkelerinde yaşlı insanların yalnız yaşam, bakım gereksinimi, sosyal hayata katılamama, yoksulluk vb. birçok sorun ile mücadele ettiği görülmektedir. Bu kapsamda Fransa'da yaşlı insanların gelir durumunun yükseltilmesi, yaşlıları topluma ve istihdama kazandırma konusunda çalışmalar yürütüldüğü, Almanya'da farklı kuşakların birbirleriyle etkileşim kurduğu ve birbirlerini destekledikleri toplum merkezleri projeler (Elmacı vd.,2015) Japonya'da yaşlı insanların bakıma gereksinimi düşünülerek emeklilik ve sağllk sigorta sistemlerinde reform iyileştirmeler (sağlık sigortası vb.) yapıldığı bilinmektedir (Erol, 2013).

\section{2. "Yaşlı Dostu Kent" Kavramına Yönelik Bir Stüdyo Deneyimi- Bolu/Karacasu Örnek Alan Çalışması}

Yaşanabilir ve yaşam kalitesi yüksek kentsel çevreler oluşturulmasında kentsel planlama ve kentsel tasarımın önemi oldukça fazladır. Fiziki yapının oluşum-gelişim kararlarını makro ölçekte eyleme alan kentsel planlama, yapılı çevreyi şekillendirirken kentsel tasarıma veri sağlamakta, parça-bütün ilişkisi bazında kentsel tasarım aracılığı ile kentsel alanları şekillendirmektedir (Kaplan vd., 2003).

Çalı̧̧ma kapsamında stüdyo deneyimi aktarılan Yaşlı Dostu Kent Modeli, Bolu Abant İzzet Baysal Üniversitesi Mimarlık Fakültesi 2019-2020 Şehircilik Projesi dersi kapsamında 3. Sınıf öğrencilerinin 4

62| P a g e

www.iiste.org 
farklı öğretim elemanı yürütücülüğündeki stüdyoda bir yürütücünün 18 kişilik öğrenci grubuna yönelik uygulanan bir stüdyo konusudur. Bu çalışmada 18 kişilik gruptan "Rüveydanur Koçak, Yasin Yıldız, Kübra Aslan, Çetin Biçer, Elif Koluş" isimli öğrencilerin Bolu-Karacasu'nun 2050 yılı vizyonu öngörülerek hazırlamış oldukları projeler değerlendirilecektir. Stüdyoda Bolu Karacasu beldesinin mevcut potansiyeli irdelenerek, insan-mekan-çevre davranış ilişkisi dikkate alınmış olup, Bolu genelinde kentsel yaşam kalitesini iyileştirmeye yönelik bir stüdyo konusu belirlenmiştir.

Yaşlı dostu kent modeli için ilk olarak makro ölçekte Bolu'nun fiziksel ve çevresel özellikleri irdelenmiş olup, konum, ulaşım ve çevre iller ile erişilebilirliği tespit edilmiştir. Sonrasında kentsel planlama ve tasarım açısından çalışma alanı Karacasu'da doğal, kültürel, sosyal, ekonomik koşulları dikkate alan bir analiz-sentez çıkarılmıştır. Yöntem açısından; SWOT analizinden yararlanılan çalışmada (Güçlü ve Zayıf Yönler, Fırsatlar, Tehditler) kentsel planlama ve tasarımı destekleyecek stratejiler için yurt dışı örnekleri ve kültürümüzden gelen şifayı doğada aramaya yönelik görüşler dikkate alınmıştır. Mimari tasarım uygulama ve araçları (2d-3d plan çizimleri, görselleştirme ve analize dayalı programlar) ile 1/5000'lik Nazım İmar Planı ve 1/1000'lik Uygulama İmar Planı hazırlanmıştır.

Batı Karadeniz Bölgesinde yer alan Bolu D-100 (E-80) karayolu üzerinde olup, İstanbul'a 262 km, Ankara'ya $191 \mathrm{~km}$. mesafede yer almaktadır. Çalışma alanı, Karacasu beldesi Bolu Merkez'e 5km uzaklıktadır (TC Başbakanlık Devlet Planlama Teşkilatı Müsteşarlığı, 2002) (Şekil 1).
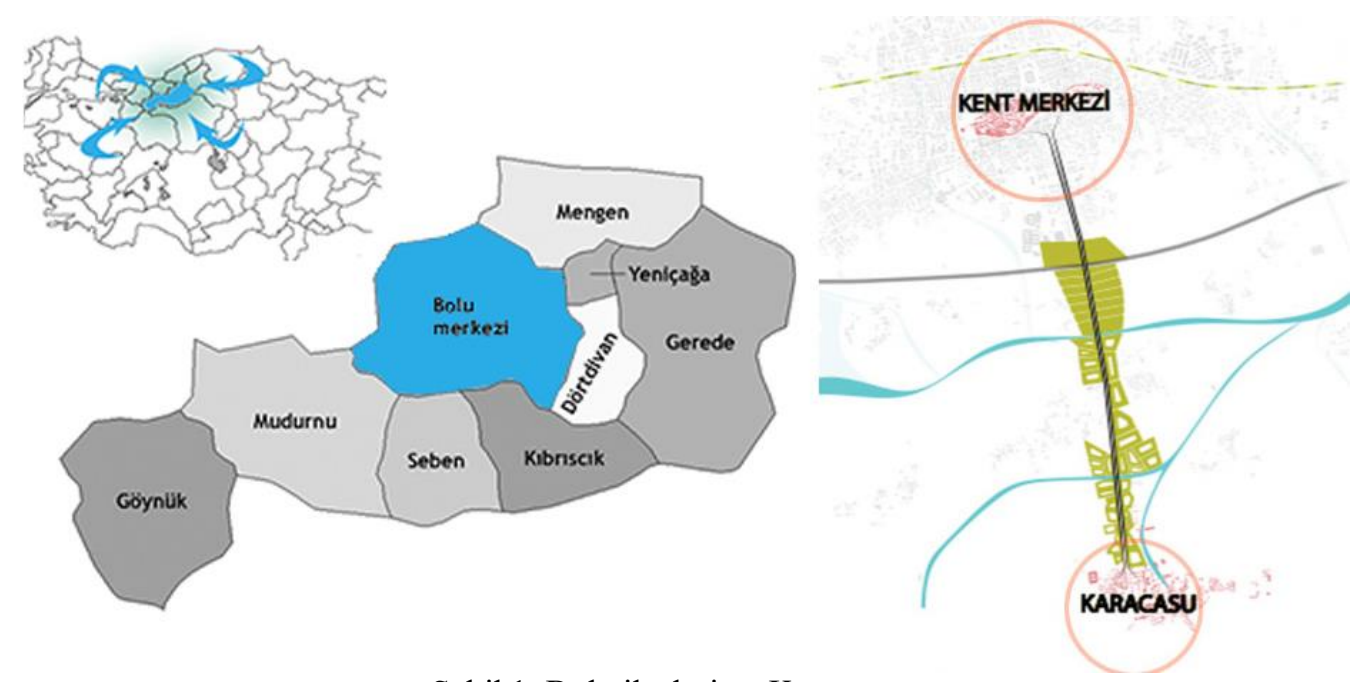

Şekil 1. Bolu ilçeleri ve Karacasu.

Şekil 1'de görüldüğü üzere Bolu ili, Bolu merkez, Dörtdivan, Gerede, Göynük, Kıbrısçık, Mengen, Mudurnu, Seben, Yeniçağ olmak üzere 9 ilçeden oluşur. Bolu Valiliği İl Nüfus Müdürlüğü 2019 yılı verilerine göre Bolu genelinde nüfus 316.216'dır. Karacasu beldesinin nüfusu ise 2540 kişi olarak tespit edilmiştir (Bolu İl Valiliği, 2019).

TÜİK verilerinde Bolu ili tümünde ise yaşlı nüfusu 40 bin 946 olarak tespit edilmiş olup, toplam nüfusun \%13,15'i kadar yaşlı nüfus olduğu dikkat çekmektedir. 81 il üzerinden yapılan istatistiksel incelemede Bolu ili \%13,13 ile yaşlı nüfusu şehirler listesinde 16. sırada yer almaktadır (T.C., Aile, Çalışma ve Sosyal Hizmetler Bakanlığı, 2018) (Şekil 2). 


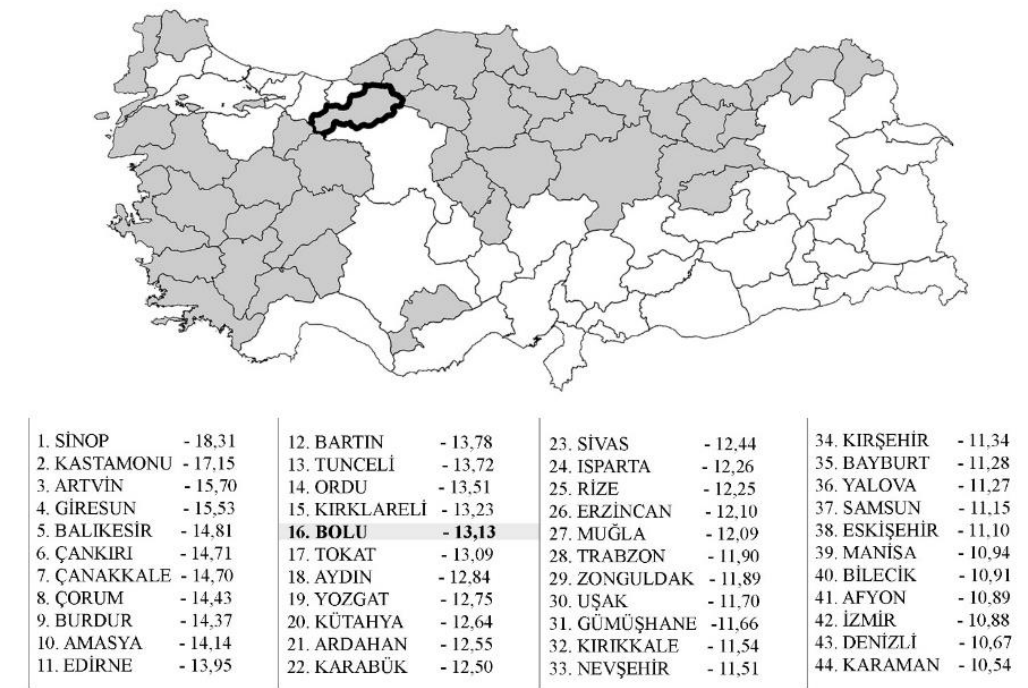

Şekil 2. Türkiye'de yaşlı nüfus yoğun iller ve Bolu ili (T.C., Aile, Çalışma ve Sosyal Hizmetler Bakanlığıı, 2018'den yararlanılarak türetilmiştir).

2019-2020 Bolu Abant İzzet Baysal Üniversitesi Mimarlık Fakültesi Şehircilik stüdyosunda Yaşlı Dostu Kent Karacasu teması çalışırken; "Yaşam kalitesini Karacasu'da nasıl geliştirebiliriz? Karacasu, Bolu geneline hatta Batı Karadeniz Bölgesine nasıl katkıda bulunabilir? soruları üzerinden yürütücü ve öğrencilerin karşılıklı etkileşimine dayanan bir kurguda Yaşlı Dostu Kent Karacasu için 1/5000 Nazım İmar Planı ve 1/1000 Uygulama İmar Planı hazırlanmıştır. Stüdyo kapsamında yapılan swot analizi (Tablo 3) sonucunda Yaşlı Dostu kent için alınan kararlar aşağıda belirtilmiştir.

-Mevcut nüfusu koruyarak, alan kullanımında erişilebilirliği dikkate alan, planlı ve dengeli bir arazi kullanımı sağlamak,

-Mevcut tarım kenti potansiyelini mümkün olduğunca korumak ve geliştirmek -2050 y1lı 10.000 kişilik nüfus öngörüsü belirlemek,

-Alanda geliştirilecek yapısal tasarımlarda jeolojik kırılganlığı ve deprem riski faktörünü dikkate almaktır.

Tablo 3: Yaşlı Dostu Kent Karacasu için Swot Analizi

\begin{tabular}{|l|l|}
\hline \multicolumn{1}{|c|}{ ZAYIF YÖNLER } & \multicolumn{1}{|c|}{ GÜÇLÜ YÖNLER } \\
\hline -Termal turizmin kent merkezi ile ilişkisinin & - Sağlık alanı açısından alanın geliştirilebilir \\
zayıf olması, & nitelikte olması, \\
-2050 yılı nüfusu ölçüt alındığında sağlık & -Termal turizmi destekleyen sıcak su kaynakları \\
açısından yetersiz olması, & (Termal Otel ve Büyük Kaplıca, Küçük Kaplıca \\
-Alanın dağınık bir yapısıl yerleşim içermesi, & Özel İdare Tesisleri bulunması) açısından \\
-Aktif nitelikli yeşil alan ağının olmayışı, & bölgenin zengin olması, \\
-Yaşlı bireyler ve hatta belde halkı için sosyal & -Mevcut hali ile Sağlık Bakanlığı'na ait 150 yatak \\
nitelikte alanların yetersiz oluşu, & kapasitesine sahip olan Fizik Tedavi ve \\
-Yaşlı bireyler için bir etkileşim alanı ya da & Rehabilitasyon hastanesinde romatizmal \\
bakım hizmet veren kuruluş olmaması, & hastalıklar, kemik ve kireçlenme hastalıkların \\
-Alan genelinde erişilebilir nitelikte yaya & tedavisinin gerçekleşmesidir. \\
merkezli bir altyapı olmaması, & \\
-Ulaşım hat güzergahları açısından yetersiz & \\
olmasıdır. & \\
& \\
& \\
& \\
\end{tabular}




\begin{tabular}{|c|c|}
\hline FIRSATLAR & TEHDİTLER \\
\hline $\begin{array}{l}\text {-Sağlık alanı açısından geliştirilebilir nitelikte } \\
\text { olması, } \\
\text {-Termal Turizmi destekleyen sıcak su tesisleri } \\
\text { bulunması (Termal Otel, Büyük Kaplıca, } \\
\text { Küçük Kaplıca Özel İdare Tesisleri), } \\
\text {-Mevcut durumda sağlık Bakanlığı'na ait } 150 \\
\text { yatak kapasitesine sahip Fzik Tedavi ve } \\
\text { Rehabilitasyon Hastanesi’nde romatizmal } \\
\text { hastalıklar, kemik ve kireçlenme üzerine tedavi } \\
\text { yapılıyor olmasıdır. }\end{array}$ & $\begin{array}{l}\text {-Çalışma alanının Kuzey Anadolu Fay Hattı } \\
\text { Üzerinde bulunmasıdır. }\end{array}$ \\
\hline
\end{tabular}

Bolu-Karacasu Yaşlı Dostu Kent konusunda örnek bir model oluşturmaya teşvik eden en önemli ilke; Tablo 3'de de belirtildiği üzere alanın Termal Turizm Merkezi olmasıve Sağlık Bakanlığı'na ait Fizik Tedavi ve Rehabilitasyon Hastanesi ile Bolu ve Batı Karadeniz Bölgesi geneline tedavi amaçlı hizmet vermesidir.

Projede DSÖ’nün belirlediği kriterler dikkate alınmış, farklı ülkelerin yaşlı kenti potansiyel arazi kullanımları değerlendirilmiştir. 1/5000'lik Nazım İmar Planı ve 1/1000 Uygulama İmar Plan kararlarında (EK 1-EK2); aktif ve sağlıklı yaşlanmayı desteklemek amaçlı;

-Alanın jeolojik risk haritasına bağlı olarak, emsal değeri düşük tutulan sosyal donatı alanları ve hizmet alanları oluşturulması, daha fazla açık alan ve nitelikli yeşil ağ morfolojisine sahip kentsel alan kullanımı,

-Ana aks üzerinde 2050 yılı 10.000 kişilik nüfus öngörüsü için ek 1700 konut+bahçe alan ayrılması,

-Tazelenme üniversitesi kapsamında genç yaşlı kuşağın iletişimi sağlanacağı atölyelerin (müzik atölyesi, yemek atölyesi, egzersiz alanı ve bitki yetiştiriciliği vb.) bulunduğu sosyal donatı alanı oluşturulması (Sosyal donatıların bulunduğu alan seçiminde Fizik Tedavi ve Rehabilitasyon Binasına yakın olması tercih edilmektedir).

- Mevcuttaki Fizik Tedavi ve Rehalitasyon binası, sosyal donatı alanları ile ilişkili olarak tedavi için gelen insanların kısa süreli kalabileceği Bungalov evler için ayrılmış günübirlik sağlık evleri ile genişletilmesi (Tek katlı, İki yataklı toplamda $100 \mathrm{~m} 2$ 'lik (50 m2 yapısal alan, $50 \mathrm{~m} 2$ açı alan/bahçe planlı iki yataklı 400 Bungalov sağlık evleri),

-20'şer sağlık evine ortak hizmet eden 400m2'lik kamusal odaklı meydanlar,

- Fizik tedavide tedavi gören hastaların aynı zamanda psikolojik olarak tazelenme ve rehabilite edilmeleri için ana yol aksından uzak sessiz ve doğa ortamı içerisinde rehabilitasyon merkezleri, şifa bahçeleri, ve meditasyon alanları oluşturulması,

-Rehabilitasyon Merkezi içerisinde sadece kapalı mekanlar değil aynı zaman da açık rehabilite alanlarının ve spor alanlarının da bulunduğu, engelli insanlara da hizmet sağlayabilecek, işitme duvarları, doku bahçeleri ve etkinlik alanları oluşturulması,

- Alanda $250.000 \mathrm{~m} 2$ alanlı, yaşlı bakım merkezi (huzur adası) oluşturulması (Her 50 evde bir $1000 \mathrm{~m} 2$ meydan alan bırakılması ve evlerin $300 \mathrm{~m} 2$ yapı- açık alan kullanımı içerisinde yaşlıların doğaya özlemlerini gidermek amaçlı $200 \mathrm{~m} 2$ bahçe-tarım alanı bırakılması),

-Alan tümünde yeşil ağlar oluşturarak, tüm kentin yeşil ağlar arasından dolaşımına imkan tanınması, bu kapsamda her dört mahallede bir $22.000 \mathrm{~m} 2$ lik kuşaklar arası etkileşim parkları oluşturulması -Alanda mevcutta bulunan kanalın geliştirilerek, iki taraflı bir kamusal dolaşım ağı sağlanması, -930.000 m2 lik kent ormanı ile bölgedeki halkın temiz oksijen ihtiyacının karşılanması,

- Rehabilitasyon merkezi alanına meditasyon, zen bahçeleri ile zihinsel ve mental rahatlama alanları oluşturulması,

-Karacasu'nun doğal biyolojik çeşitliliğini Osmanlı Şifa Bahçesi amaçlı kurulan tarh alanları ile zenginleştirilmesi,

- İlaç yapımında şifalı bitki türleri için Fizik Tedavi ve Rehabilitasyon Hastanesine yakın şifa tarh bahçeleri oluşturulması,

- Alanda kent içi erişilebilir yaya ağı oluşturulması (genişletilmiş kaldırım zonları, paylaşımlı cadde uygulamaları, bisiklet yolları, alanda yürümeyi ve engelli arabası ile dolaşmaya firsat veren \%4'ü geçmeyen arazi eğimi vb.).

-Kuşaklar arası etkileşim park alanları (yaşl1- genç-çocuk vb.) oluşturulması,

65 | P a g e

www.iiste.org 
-Yaşlıları aktif yaşama kazandıran ve üretkenliğini artıran permakültür bahçeleri oluşturulması,

-Tarım alanları ve meyve bahçeleri ile kentteki yaşlıların sosyal aktivite ve organik gıda ihtiyacının karşılanması,

--Konut alanları ve yaşlı bakımı için ayrılan sosyal hizmet alanlarının güneşi gören ve dışarıya seyir imkanı tanıyan özellikte tasarlanması,

- Acil durumlarda ve doğal afetler için $170.000 \mathrm{~m} 2$ alana sahip, 10.000 kişiye hizmet edebilecek özellikte toplanma alanları oluşturulması şeklinde belirtilen stratejilere yönelik stüdyo projesi önerilmiştir.

Stüdyo kapsamında önerilen planlama ve tasarım kararlarında Karacasu beldesinde yaşayanların konutları için de alanın tarım potansiyelinden yararlanmalarını sağlamak için tek katlı bahçeli konut projeleri planlanarak, emsal değerlerine uygun olmayan konutlarda yerinde kentsel dönüşüm ve sağlıklaştırma önerilmiştir.

\section{Sonuc}

Yaşlılık, insan yaşamının en kaçınılmaz dönemidir. Yaşlı insanların, yasam kalitesinin yükseltilmesinde günlük yaşamını geçirdiği konut modeli, mahallesi, sokağı, alıştığı semtin taşıdığı özellikler ve çevre koşulları önem kazanır. Yaşlı insanların gündelik yaşama aktif, sağlıklı ve güvenli katılımı, uygun ortamın hazırlanması ve katılımı engelleyen olumsuzlukların iyileştirilmesi ile mümkündür.

Stüdyo çalışmasında Bolu Karacasu'da yaşlı dostu kent modeli üzerine proje geliştirilmesinin temel amacı; Karacasu'nun termal sağlı altyapısına sahip olması, Fizik tedavi ve Rehabilitasyon Hastanesinin hem Karacasu ve çevre illerde(Batı Karadeniz illeri) yaşayan hastaların şifa noktası olması, doğa ile bütünleşik kırsal çevresi ve Bolu merkeze erişilebilir konumda bulunmasıdır. Ayrıca genel anlamda Batı Karadeniz bölgesinin Türkiye genelinde yaşlı nüfusu en yoğun iller (\%18.31 ile Sinop, \%17.15 ile Kastamonu) sıralamasında yer alması da Bolu-Karacasu'yu yaşlı dostu kent modeli çalışmada yönlendirici etken olmuştur.

Stüdyoda, öğrencilere kentsel planlama ve kentsel tasarım dinamiklerine bütüncül bakabilme yetisi kazandırılmış, makro ölçekten- mikro ölçeğe kenti bir bütün olarak yorumlama, yaratıcı ve eleştirel düşünceyi geliştirme, kentsel ve mimari tasarım-kuram oluşturmada doğal ve kültürel peyzaj dinamiklerinin kent için kararlar almada yönlendirici unsurları deneyimlenmiştir. Özellikle öğrencilerin üst ölçekli arazi kullanımı kararlarında parça-bütün ilişkisini dikkate alan, planlama- tasarım açısından yönlendirici güncel perspektiflere ilişkin çözümler üretmesi stüdyonun temel hedefini karşılar nitelikte sonuçlar çıkarmıştır.

Ülkemizde Onuncu Kalkınma Planında "insan odaklı kalkınma anlayışı çerçevesinde katılımcı bir yaklaşım" üzerinde durulmaktadır. Her yaş grubu için "nitelikli insan, güçlü toplum" alanlarında öncelikli dönüşüm programları belirlenmiştir. Yaşlanma ile ilgili olarak "aktif yaşlanma", "yaşlı bakım modelleri", "yaşlanma konusunda veri kaynakları" , "sosyal içerme", "kurumsal altyapının geliştirilmesi", ve konuları ele alınmaktadır. Özellikle aktif yaşlanma konusu "yaşam kalitesini geliştirme" kapsamında sorgulanmaktadır (T.C. Kalkınma Bakanlı̆̆ Onbirinci Kalkınma Planı, 2018). "Sağlıklı Yaşam ve Hareketlilik Programı" kapsamında yaşlı nüfusu da ilgilendiren politikalar geliştirilmesi vurgusu yapılmıştır.

Çalışma kapsamında belirtildiği üzere, yaşlı kentlerin en önemli özelliği yaşlı, genç, çocuk farklı tüm yaş grupları arasında aktif yaşama kazandırmaktır. Dünya Yaşlanma Toplantılarında; tüm dünya ülkelerinde, sağlıklı yaşlanma, etkileşimli yaşlanma, huzurlu yaşlanma, aktif yaşlanma, sosyal katılımlı yaşlanma, öğrenerek yaşlanma kavramlarına dikkat çekilmektedir

Stüdyo kapsamında da Bolu Karacasu'da sağlıklı yaşlanma açısından sağlık tesisleri geliştirilmiş, evde bakım ya da Bungalov tipi sağlık evleri ile günlük bakım hizmeti sunulması amaçlanmıştır. Etkileşimli ve aktif yaşlanma olarak, kuşaklararası etkileşim parkları, tazelenme üniversitesi vb. etkinlik mekanlarına yer verilmiştir. Huzurlu yaşlanma açısından doğa, yeşil altyapı açısından zengin olan Karacasu'nun mevcut özelliğini geliştirerek, özellikle erişilebilirliği artıran kentsel çözümler önerilmiştir. Yaşlı dostu kentlerde "gönüllük çalışmaları" önem kazandığı için Karacasu'da gönüllü toplum kuruluşları eşliğinde kuşaklar arası yaratıcılık kurs birimleri olușturulmuş olup, hem toplumsal katılım hem de yaşlanmayı olumlamayı içeren farklı yaş gruplarının birbirine öğreticiliğini artıran, etkinlikler düzenlemeye olanak veren mekan çözümleri geliştirilmiştir. Oluşturulan zen bahçeleri, Osmanlı şifa bahçeleri ile de doğa ile bütünleşik sağlık tarhları oluşturulmuş, geleneksel şifa bahçeciliği kültürü yaşatılması istenmiştir.

Üst ölçek plan kararları ile çalışma alanı mevcut özelliklerinin ortak sentezinin yapıldığı Stüdyo çalışmasında kentsel planlama ve tasarım süreci, kavramlar üretme yaklaşımı ile ele alınmaktadır.

66 | P a g e

www.iiste.org 
Böylece sorgulayabilen ve yaşadığı sorun karşısında alternatif çözüm geliştirebilen, öngörüsü yüksek; mimar-plancı mezun vermek amaçlanmaktadır. Bu analiz-sentez ilişkisine dayalı proje geliştirme yetisi öğrencilerin meslek yaşamlarında bir deneyim kazanımı sağlaması açısından da önemlidir. Öğrenciler stüdyo projesi ile

-Planlama ve tasarıma; bağlamsal, kavramsal olgular ile ele alabilme,

-Kent, yapılı çevre, yerel halkın sorun ve ihtiyaçlarını yorumlayabilme, çözüm geliştirme ve şematik kavram yetisi kazanma,

-Kentte karşılaşılan bir problem çözümü için doğal çevre verilerini maksimum oranda fayda oluşturarak değerlendirme,

-Kentsel alan planlaması ve tasarımında karar alırken makro ölçekten mikro ölçeğe bütüncül ve sürdürülebilir, birbirini destekleyen öneriler üretebilme, fonksiyonel ve görsel ilişkiler aracıllğı ile bunu aktarabilme,

-Mevcut çevreye yapılacak her bir müdahalenin orada toplumsal, sosyal, ekonomik yapıyı da beraberinde etkilediğini anlama açısından önemli deneyimler elde etmektedir (Kuloğlu, 2014; Kaplan vd., 2003).

Bu kapsamda "Yaşlı Dostu Karacasu stüdyo çalışması, aktif ve sağlıklı yaşlanma için bir yaş dostu şehir modeli geliştirme açısından, yaşam kalitesini yükseltmeyi hedefleyen mekânsal stratejik çözümleri ile emsal oluşturabilecek nitelikte bir projedir. Karacasu beldesi üzerinden öğrencilere fiziksel, sosyo-kültürel ve sosyo-ekonomik bağlamlarda çok boyutlu, esnek, katılımcı, bütüncül ve sürdürülebilir özellikte mekânsal strateji üretebilme yetisi kazandırılmıştır. Mimarlık-Planlama-Peyzaj disiplinleri arasındaki bağın birbiri ile koordineli bir şekilde anlatıldığı stüdyoda öğrenciler, ileriki meslek yaşamları için yapılı çevre üretimi ve uygulaması konusunda ekip çalışması, güçlü işbirliğinin önemini deneyimleme firsatı da bulmuştur.

4.Teşekkür: 2019-2020 Bahar dönemi Bolu Abant İzzet Baysal Üniversitesi Mimarlık Fakültesi Mimarlık Bölümü Şehircilik Stüdyosu Projesinde "Yaşlı Dostu Kenti Karacasu" çalışma önerisi üzerine azim ve kararlılıkları ile çalışmayı kabul eden ve proje geliștiren 3.snnf öğrencileri; "Rüveydanur Koçak, Yasin Ylldız, Kübra Aslan, Çetin Biçer, Elif Koluş”a proje yürütücüleri olarak teşekkür ederim.

\section{Kaynaklar}

Akıncıtürk, N.,Keskil, A.T., 2019," Yaşlı Dostu Kentler ve Yaşlı Bireylerin Kent Yaşamına Aktif Katılımı" http://www.skb.gov.tr/yas - li - dostu - kentler - ve-yasli-bireylerin - kent- yasamina aktif - katilimi - s31323k .

Arpacı,S.,"Yaşlı Bireylerin Yaşam Kalitesi Açısından Günlük Yaşam Aktivitelerini Yapabilme Durumunun İncelenmesi" Yaşlı Sorunları Araştırma Dergisi, 2015(1):46-53

Arthur, P.,\&Passini, R. (1992). Wayfinding: People, signs, andarchitecture. New York: McGrawHillBookCo.

Aslan D., 2009, "Yaşlılık döneminde yaşam kalitesi kavramı: Kadın sağlı̆̆ı bakış açısı". Yaşlanan Kadın Sempozyumu. http:// www.huzurevleri. org.tr/docs/ Yaslilik_ Doneminde_ Yasam Kalitesi_Kavrami.pdf.

Bolu İl Valiliği, 2019, "Nüfus Yapısı”. http://www.bolu.gov.tr/nufus-yapisi.

Caner, Ö.,Gözün,G., Hilwah, A., Gökçek, M., 2013, "Yaşlı Dostu Şehirler: Kavramsal Çerçeve Ve Örneklerle Değerlendirmeler" Güneş Tıp Kitabevleri, ISBN: 978-975-277-524-4,s.23,Ankara, http://www.geriatri.org.tr/pdf/Yasli_Dostu_Sehirler_Baski11_11_2013.pdf.

Carstens, D. Y. (1985). Site Planning and Design forTheElderly. New York, 1985.

Çifcili,, S.,2016. "Aktif Yaşlanma: Fiziksel Boyut" TurkishFamilyPyhsician” CILt 3, Sayı:1, http://turkishfamilyphysician.com/wp-content/uploads/2016/08/C3-S1-aktif-yaslanma-fizikselboyut.pdf. 
Elmac1, D., Ergin,S.,2015, "Beden, Ruh Ve Zihin İçin Gıda Projesinde Aktif Yaşlanma Ve Kuşaklararası Dayanışma Örnekleri”, Yaşı Dostu Kentler Sempozyumu Bildiri Kitabı, ISBN 978-605-462-883-4, Bursa, https://ailevecalisma. gov. tr / media / 2625 / yasli- dostu- kentlersempozyumu.pdf).

Erol, S.I.,2013, "Japonya'da Yaşlılara Yönelik Sosyal Politikalar" İş Güç İnsan Kaynakları ve Endüstri İlişkileri Dergisi. Cilt/Vol: 15, Sayı/Num: 3, Page: 49-63 ISSN: 1303-2860, DOI: 10.4026/1303-2860.2013.0231.x, file:///C:/Users/Asus/Downloads/516.pdf.

Hoof, J.V.,Dikken,J.,Buttigieg,S.C., Hoven, R.F.M.,Kroon, E.,Marston, H.R.,2019, “Agefriendlycities in the Netherlands : an explorativestudy of facilitators and hindrances in the built environment and ageism in design"Indoorand Built Environment. 2020, Vol. 29(3) 417-437. https://doi.org/10.1177\%2F1420326X19857216.

Jönsson, Ann, 2018," A better environment to age in - Working Towards Age -friendlycities in the Nordicregion", $T B$ Screen AB. ISBN: 978-91-88213-28-0. The Nordic Welfare Centre, Finland. https://nordicwelfare.org/wp-content/uploads/2018/03/A-better-environment-to-age-in.pdf.

Kalınkara, V., 2015, "Yaşanabilir Toplumlar Ve Sürdürülebilir Yerinde Yaşlanma" Bursa Yaşlı Dostu Kentler Sempozyumu Bildiri Kitabı, ISBN 978-605-462-883-4, s. Afşar Matbaacılık, Ankara.

Kalınkara,V.,2017, "Yaşlanan Kentler: Kentsel Alanda Aktif Yaşlanmayı Destekleyecek Kapsayıcı Tasarım ve Ergonomi”" Tematik Yazılar, Toplum ve Demokrasi, 11 (24), Temmuz-Aralık, 2017, s. 229-248.

Kaplan, H., Bayraktar, N., Tekel, A., Çalgüner, T.,Yalçıner, Ö.,2003, "Kentsel Tasarım Süreci Ve Yöntemine İlişkin Bir Alan Çalışması; Çeşme-Dalyan Yerleşiminde Yeni Bir Yöntem Denemesi” Gazi Üniversitesi Mühendislik ve Mimarlık Fakültesi Dergisi Cilt 18, No 2, 1-15, 2003, Ankara.

Koçak, o.,2018, "Sosyal Politika Bağlamında Yaşlanma", İstanbul Üniversitesi Açık ve Uzaktan Eğitim Fakültesi Ders Notları, http://auzefkitap. istanbul.edu.tr/kitap/yasli_bakimi_onlisans ao/aktif_ve_saglikli_yaslanma.pdf.

Kozak, M.A.,Acar, D.,Çiftçi,E.B.,2019 "Üçüncü Yaş Turizminin Geliştirilmesinde Yaşlı Dostu Şehir (YDŞ) Teması” Turizm Akademik Dergisi.02 (2019) 99-114).

Kuloğlu, N.,2014, "Mevcut Çevrede Tasarım: Stüdyo Deneyimleri” Nobel Akademi Yayıncllı Eğitim ve Danışmalık. ISBN: 978-605-133-750-0, Yayın no: 848, Mimari Sanat no:003, ,s. 125, Ankara.

Kuş, M.,2019, "Huzurevi Tasarımında Kullanıcı Fktörleri Etkisinin Değerlendirilmesi” İstanbul Aydın Üniversitesi Fen Bilimler Enstitüsü, Mimarlık Tezli Yüksek Lisans, İstanbul.

Murakami, İ.,2015" "Türkiye'deki Kuşaklararası İlişkileri Geliştirme Uygulamaları" Yaşlı Dostu Kentler Sempozyumu, Türkiye Sosyal Araştırmalar Dergisi-2017, https://dergipark. org.tr/tr/ download/article-file/355959.

Özdemir,A.,2017 "Kuşaklar Arası Etkileşim: Aktif Park"https://www.arkitera.com/gorus/kusaklararasi-etkilesim-aktif-park/;

Palaz,F.S., 2020, "Çözüm Üreten Kentler -Yaş Dostu Kentler İçin İyi Uygulamalar" Kent Dergisi. Marmara Belediyeler Birliği, Sayı: 001-2020, ISSN: 2717-7343, http://marmara.gov.tr/ UserFiles/Attachments/2020/04/30/6754ad06-ee66-44e4-b09b-96b7511140c6.pdf). 
Peponis, J.,Wineman, J., Dalton, N. (1990). FindingtheBuilding in Wayfinding. Environment and Planning B: Planning and Design. Vol. 31, pp. 453-473.

T.C. Amasya Üniversitesi, 2011, "Yaşlı Dostu Kent: Amasya" T.C. Kalkınma Bakanlığı ve OrtaKaradeniz Kalkınma Ajansı. https://www.oka.org.tr/assets/upload/dosyalar/104yasli-dostukent-amasya_v2.pdf.

TC Başbakanlık Devlet Planlama Teşkilatı Müşteşarlığı, 2002, "Bolu İli Raporu” ISBN 975 -192992x,http://www.sbb.gov.tr/wp-content/uploads/2018/11/BoluIli Raporu\%E2\%80\%8B.pdf,Bolu.

T.C. Kalkınma Bakanlığı Onbirinci Kalkınma Planı, 2018, "Yaşlanma Özel İhtisas Komisyonu Raporu"http://www.sbb.gov.tr/wp-content/uploads /2020/04/Yaslanma Ozel Ihtisas Komisyonu Raporu.pdf.

T.C., Aile, Çalışma ve Sosyal Hizmetler Bakanlığı, 2018, “İL YERLEŞİM YERLERİ YAŞLI NÜFUSUNUN ADRESE DAYALI NÜFUS KAYIT SISTEMİ (ADNKS) 2018 VERİLERINE GÖRE DAĞILIMLARI VE ORANLARI” https://ailevecalisma.gov.tr/media/5200/2018-ilyerlesim-yerleri.pdf.

Turgut, H.,İşbakan, N., 2019, "Yeni Yaşam Biçimleri Üzerine Denemeler:Bir Mimari Tasarım Stüdyosu Deneyimi” MEGARON 2019;14 (SUPPL. 1):70-82, DOI: 10.14744/MEGARON.2019.48295.

Tutal, O.,Üstün,B., 2009, "Yaşlılık ve Yaş Dostu Kentler: Eskişehir" Yaşlı Sorunları Araştırma Dergisi, 2009 (1): 1-23.

United Nations, (2015) "World PopulationAgeing 2015". Department of Economic and Social Affairs, Population Division. (ST/ESA/SER.A/390). New York.

URL 1: https://www.who.int/ageing/publications/Age_friendly_cities_checklist.pdf.

Ünlü, A, 2018, “Ekolojik Adaptasyon, Yaşlılık ve Mimarlık, http://www.skb.gov.tr/wpcontent/uploads/2018/10/Prof.-Dr.-Alper-Unlu.pdf.

Van Hoof, J.; Kazak, J.K.; Perek-Białas, J.M.; Peek, S.T.M. 2018, "Thechallenges of urban ageing: Makingcitiesage-friendly in Europe". Int. J. Environ. Res. PublicHealth 2018, 15, 2473. [CrossRef] [PubMed.

Yanardağ, U.,2019. "Yaşlılarla Hak Temelli Çalışma” Yaşlılıkta Sosyal Hizmet. Nika Yayınları. ISBN: 978-605-9386-57-9https://www. researchgate.net/ publication/338402393 YASLI LARLA HAK TEMELLI CALISMA.

Yıldızak, G.B., 2017, "Yaşlı Dostu Kent Çanakkale Analizi” https://www. akademikkaynak. com/yasli- dostu-kent-canakkale-analizi.html. 
EK 1: Yaşı1 Dostu Kent: Bolu-Karacasu Stüdyo Deneyimi1/5000 Nazım İmar Planı

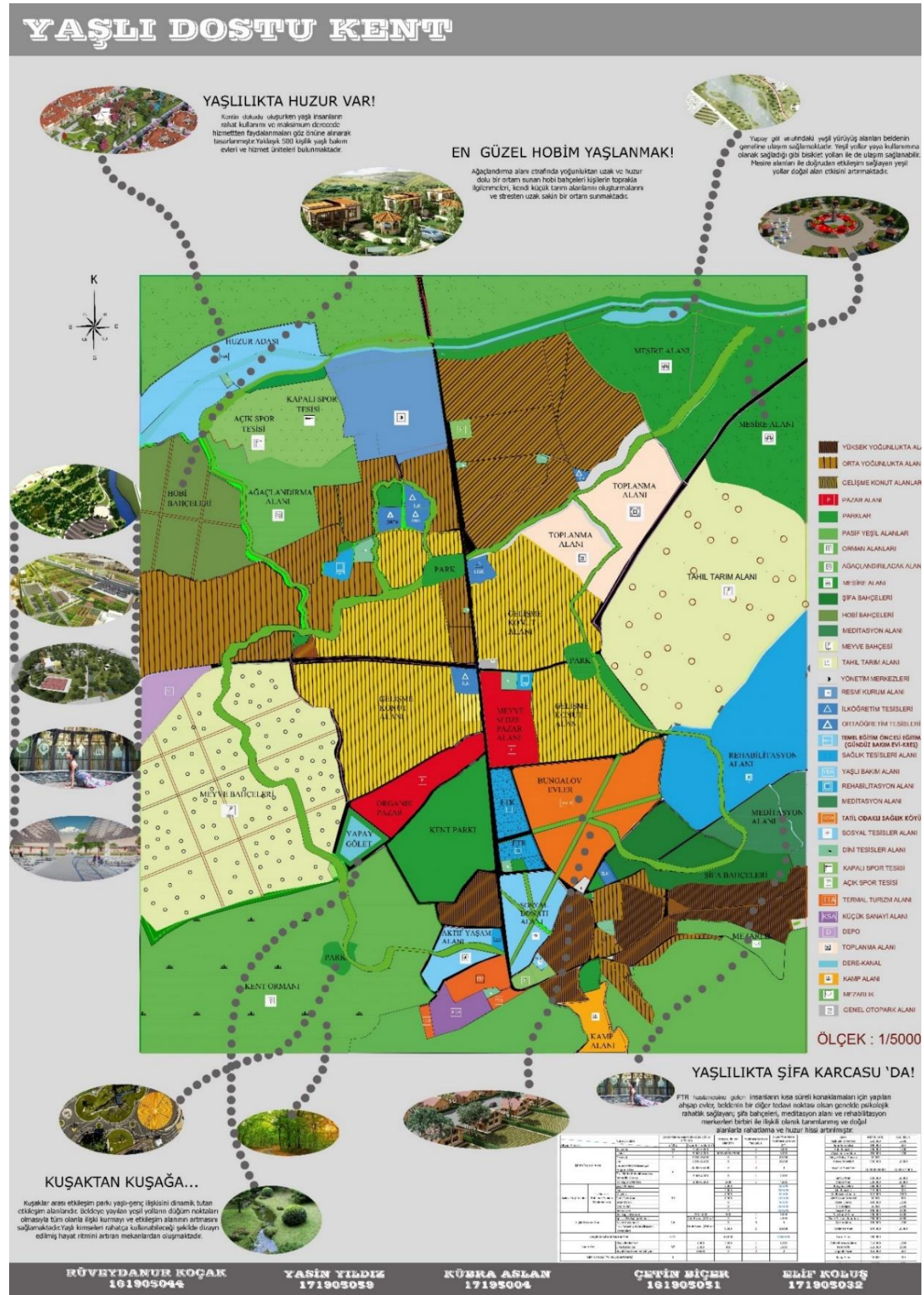


EK 2: Yaşlı Dostu Kent: Bolu-Karacasu Stüdyo Deneyimi 1/1000 Uygulama İmar Planı.

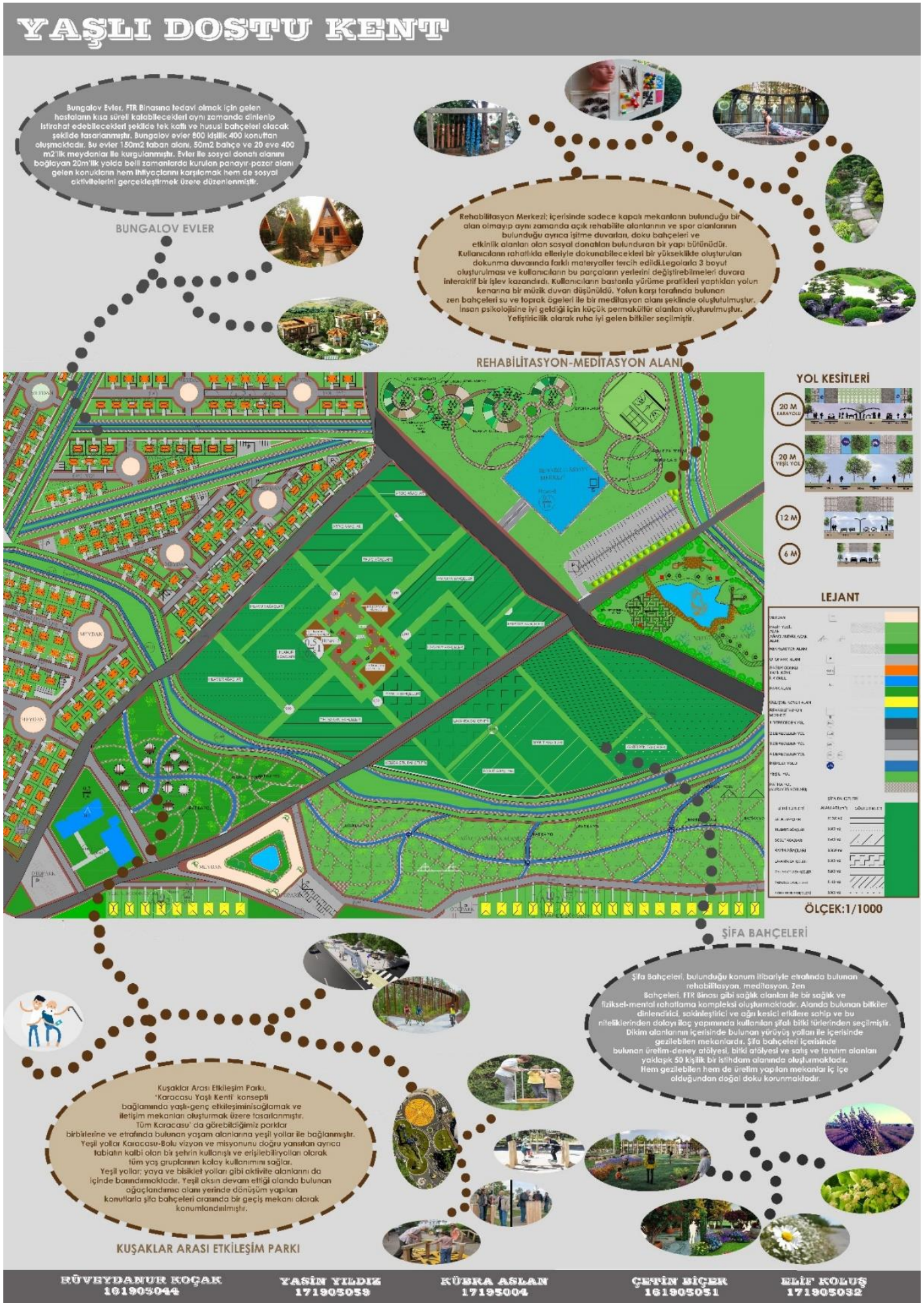

71 I P a g e 